\title{
REGULATION OF ANDROGEN RECEPTOR MRNA AND PROTEIN IN THE RAT TESTIS BY TESTOSTERONE
}

\author{
Leen J. Blok, ${ }^{1}$ John M. S. Bartlett, ${ }^{2}$ Joan Bolt-de Vries, ${ }^{1}$ Axel P. N. Themmen, ${ }^{1}$ Alber T O. \\ Brinkmann, ${ }^{1}$ Gerhard F. Weinbauer, ${ }^{2}$ Eberhard NieschlaG ${ }^{2}$ and J. Anton Grootegoed ${ }^{1}$ \\ 'Department of Endocrinology and Reproduction, Medical Faculty, Erasmus University Rotterdam, P.O. \\ Box 1738, 3000 DR Rotterdam, The Netherlands and ${ }^{2}$ Max Planck Clinical Research Unit for \\ Reproductive Medicine and Institute of Reproductive Medicine of the University, Steinfurter Straße 107, \\ 4400 Münster, Fed. Rep. of Germany
}

\begin{abstract}
Summary-Adult rats were treated with ethane dimethane sulphonate (EDS), an agent that destroys Leydig cells. Within 5 days after EDS treatment, the levels of testosterone (T) in the circulation and in the testis were decreased to very low values, which makes it possible to manipulate the testicular $\mathrm{T}$ concentration through administration of exogenous $\mathrm{T}$. Spermatogenesis was not markedly affected within 5 days after EDS treatment, also not in the absence of $\mathrm{T}$ administration.

In testes of EDS-treated rats, the androgen receptor mRNA (ARmRNA) level remained unaltered for 5 days. In ventral prostate, however, this treatment caused a pronounced upregulation of the level of ARmRNA, which could be counteracted by implantation of silastic $T$ implants immediately after EDS treatment.

In EDS-treated rats carrying a $T$ implant and in untreated rats, the same number of specific [ $\left.{ }^{3} \mathrm{H}\right] \mathrm{R} 1881$ binding sites was observed using a total testis nuclear fraction (Scatchard analysis). In testes from EDS-treated rats without $T$ implants, androgen receptors (AR) did not fractionate into the nuclear fraction; however, the total testicular AR content in these animals (measured by nuclear $\left[{ }^{3} \mathrm{H}\right] \mathrm{R} 1881$ binding after receptor transformation through injection of a high dose of $\mathrm{T}, 2 \mathrm{~h}$ before killing the rats) remained unaltered.

Immunoprecipitation and Western blotting using anti $\mathrm{N}$-terminal antibodies seemed to indicate that the total testicular amount of $A R$ protein in the EDS-treated rats was very low as compared to that in EDS-treated rats carrying $\mathrm{T}$ implants and in untreated rats. Even after receptor retransformation (by injection of a high dose of $T$ ) the receptors were not quantitatively detected by immunoprecipitation and Western blotting. This may point to a structural modification of the AR that occurs in the prolonged absence of androgens.
\end{abstract}

\section{INTRODUCTION}

During fetal and postnatal life, androgens play a crucial role in male development. The present work relates to the role of androgens in the initiation and maintenance of spermatogenesis [1]. In different androgen dependent tissues, testosterone and dihydrotestosterone interact with the androgen receptor and regulate a number of different processes. It is generally believed that upon androgen binding the receptor is transformed to a DNA binding form that regulates the expression of androgen-dependent genes $[2,3]$. In ventral prostate, a well studied androgen-dependent tissue, the androgen receptor mRNA and protein levels are both regulated by androgens. The number of androgen recep-

Proceedings of the VIIIth International Congress on Hormonal Steroids, The Hague, The Netherlands, 16-21 September 1990.

*To whom correspondence should be addressed. tors is decreased in the absence of androgens, while under the same experimental conditions the amount of androgen receptor mRNA is increased $[4,5]$. From experiments using cultured cells of different origin, it has been concluded that the androgen receptor protein is unstable in the absence of androgens [6,7].

The regulation of the androgen receptor mRNA and protein in the testis in vivo is not extensively documented. Using isolated cells from the testis, however, more data have become available. Buzek and Sanborn [8] have described an increase in androgen receptor number during postnatal testis development, in cultured Sertoli cells and freshly isolated Leydig cells but not in cultured peritubular myoid cells. In cultured Sertoli cells from immature rats, Verhoeven and Cailleau [9] have shown an additive stimulatory effect of FSH and testosterone on the androgen receptor protein $\left(\left[{ }^{3} \mathrm{H}\right]\right.$ Mibolerone binding). Androgen 
Table 1. $\left[{ }^{3} \mathrm{H}\right] \mathrm{R} 1881$ binding data and post mortem hormonal parameters from animals treated with EDS and substituted with testosterone and/or FSH

\begin{tabular}{lccccc}
\hline & $\begin{array}{c}\text { Testis weight } \\
(\mathrm{mg})\end{array}$ & $\begin{array}{c}\text { FSH } \\
(\mathrm{ng} / \mathrm{ml})\end{array}$ & $\begin{array}{c}\text { Serum T } \\
(\mathrm{nmol} / \mathrm{l})\end{array}$ & $\begin{array}{c}\text { Testicular T } \\
(\mathrm{ng} / \mathrm{g})\end{array}$ & $\begin{array}{c}\text { Nuclear AR } \\
(\%)\end{array}$ \\
\hline Control & $1583 \pm 95$ & $\mathbf{8 . 1} \pm 1.8$ & $7.4 \pm 6.0$ & $47.6 \pm 33.0$ & 100 \\
Control + T-pulse & $1517 \pm 73$ & $6.6 \pm 7.2$ & $470.0 \pm 110.0$ & $115.3 \pm 27.6$ & $104 \pm 21$ \\
EDS & $1432 \pm 46$ & $13.3 \pm 3.7$ & $<0.3$ & $2.2 \pm 2.5$ & $8 \pm 7$ \\
EDS + T-pulse & $1413 \pm 54$ & $10.1 \pm 1.7$ & $555.0 \pm 87.0$ & $74.4 \pm 27.4$ & $97 \pm 17$ \\
EDS + T & $1502 \pm 41$ & $2.3 \pm 0.6$ & $45.3 \pm 8.1$ & $10.4 \pm 1.0$ & $81 \pm 11$ \\
EDS + T + T-pulse & $1563 \pm 64$ & $2.6 \pm 0.9$ & $409.0 \pm 163.0$ & $76.0 \pm 12.6$ & $113 \pm 24$ \\
EDS + T + FSH & $1555 \pm 171$ & $8.7 \pm 0.9$ & $38.4 \pm 8.1$ & $11.1 \pm 1.3$ & $132 \pm 35$ \\
EDS + T + FSH + T-pulse & $1667 \pm 109$ & $7.5 \pm 1.0$ & $510.0 \pm 160.0$ & $99.3 \pm 18.7$ & $139 \pm 13$ \\
EDS + FSH & $1441 \pm 97$ & $19.3 \pm 2.7$ & $0.4 \pm 0.4$ & $0.8 \pm 1.3$ & $<5$ \\
EDS + FSH + T-pulse & $1402 \pm 62$ & $17.2 \pm 2.4$ & $449.0 \pm 77.2$ & $89.0 \pm 17.3$ & $78 \pm 9$ \\
\hline T-puls
\end{tabular}

$\mathrm{T}$-pulse $=$ testosterone injection $(10 \mathrm{mg}) 2 \mathrm{~h}$ prior to killing; EDS $=$ killed 5 days after EDS treatment; $\mathrm{T}=$ substitution with testosterone for 5 days $(15 \mathrm{~cm}$ silastic implants); FSH = substitution with FSH for 5 days $(2 \times 5$ IU injected per day). Results represent mean $\pm S D$ of 5 rats in each group. The nuclear AR was estimated using 3 different preparations of testicular nuclei.

receptor mRNA expression in these cells, however, was stimulated only by FSH but not by testosterone [10].

In the present study, ethane dimethane sulphonate (EDS; an alkylating agent that destroys Leydig cells in rats through an unknown mechanism) was used to deprive the testes of adult rats of testosterone within 3 days [11]. EDS treatment was followed by administration of either no hormone, or testosterone and/or FSH for 5 days. Data on androgen receptor mRNA expression were obtained using Northern and dot-blot analysis. The androgen receptor protein level was estimated by $\left[{ }^{3} \mathrm{H}\right] \mathrm{R} 1881$ binding, and by immunoprecipitation and Western blotting.

\section{THE ANDROGEN RECEPTOR MRNA}

Treatment of adult rats with EDS resulted in an undetectable level of serum testosterone and a very low level of testicular testosterone, but did not lead to a noticeable impairment of spermatogenesis and did not affect testis weight (Table 1).
Using Northern blot analysis, $10 \mathrm{~kb}$ and $4-5 \mathrm{~kb}$ bands were detected by hybridizing to the cDNA (Fig. 1). The $10 \mathrm{~kb}$ band is considered as the intact androgen receptor mRNA, with a length that is in agreement with the length of the cloned cDNAs and the genomic organization of the androgen receptor $[12,13]$. The $4-5 \mathrm{~kb}$ band is thought to represent a cross-hybridization artifact of the labeled probe with ribosomal RNA [5]. In the present experiments, however, it is shown that spleen total RNA, which contains very little androgen receptor mRNA, did not cross-hybridize with the cDNA probe, indicating that the $4-5 \mathrm{~kb}$ band does not represent ribosomal RNA. Furthermore, when ventral prostate RNA was incubated at room temperature for $48 \mathrm{~h}$, the $10 \mathrm{~kb}$ mRNA was broken down to a $4-5 \mathrm{~kb}$ band. It is concluded that the $4-5 \mathrm{~kb}$ band is a breakdown product of the $10 \mathrm{~kb}$ androgen receptor mRNA (Fig. 1). This validates the use of dot-blot analysis of total RNA to estimate androgen receptor mRNA expression.

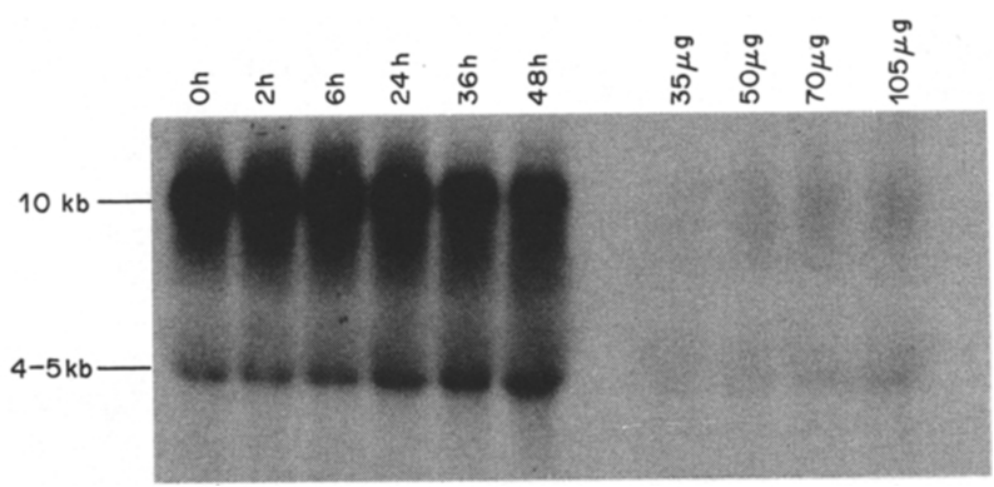

Fig. 1. Northern analysis of total RNA extracted from spleen and ventral prostate. Different amounts of spleen RNA were applied per lane $(35,50,70$ and $105 \mu \mathrm{g}$ RNA). The ventral prostate RNA $(35 \mu \mathrm{g})$ was kept for $0,2,6,24,36$ and $48 \mathrm{~h}$ at room temperature. 


\section{REGULATION OF ANDROGEN RECEPTOR mRNA EXPRESSION}

An increased level of androgen receptor mRNA was observed in the ventral prostate of the EDS-treated rats (Fig. 2a). This indicates that treatment with EDS without substitution of testosterone, has an effect comparable to that of castration on androgen receptor mRNA expression in the ventral prostate [13].

Under the present experimental conditions, no testosterone-dependent change in androgen receptor mRNA expression in the testis was observed (Fig. 2b). It is true that following EDS treatment the testicular testosterone concentration does not drop as fast as the serum testosterone concentration, and it cannot be excluded therefore that the testes were deprived of testosterone only for a relatively short time period during the 5 days following the EDS treatment. To study this point, EDS-treated rats were killed 7 days after treatment, but even then no change in testicular androgen receptor mRNA expression was detected. Furthermore, seminiferous tubules were isolated 5 days after EDS treatment and incubated for $20 \mathrm{~h}$ in the presence or absence of testosterone. In these tubules, down regulation of the androgen receptor mRNA expression by testosterone was not observed.

\section{ANDROGEN BINDING}

For estimation of the specific $\left[{ }^{3} \mathrm{H}\right] \mathrm{R} 1881$ binding sites (Scatchard analysis), a nuclear fraction was isolated from total testis. The procedure for isolation of the nuclear fraction included tissue fractionation under liquid nitrogen and the use of buffers containing a high concentration of sucrose [14], in order to prevent loss of nuclear androgen receptor. The total amount of androgen receptors in the testis estimated using this method, was in agreement with published results [8].

Treatment of EDS-treated rats with silastic testosterone implants for 5 days resulted in a testicular testosterone level at approximately $20 \%$ of the control value (Table 1). The $\left[{ }^{3} \mathrm{H}\right] \mathrm{R} 1881$ binding level in the testicular nuclear fraction of these testosterone substituted animals, however, remained unaltered as compared to control animals (Table 1, group 5). In testes deprived of testosterone, very low binding of $\left[{ }^{3} \mathrm{H}\right] \mathrm{R} 1881$ in the nuclear fraction was observed (Table 1, groups 3 and 9). This is most likely not explained by a cytoplasmic localization of the unoccupied receptor. Recently Husmann et al. [15] reported nuclear localization of the androgen receptor in the presence as well as in the absence of ligand. In the present study

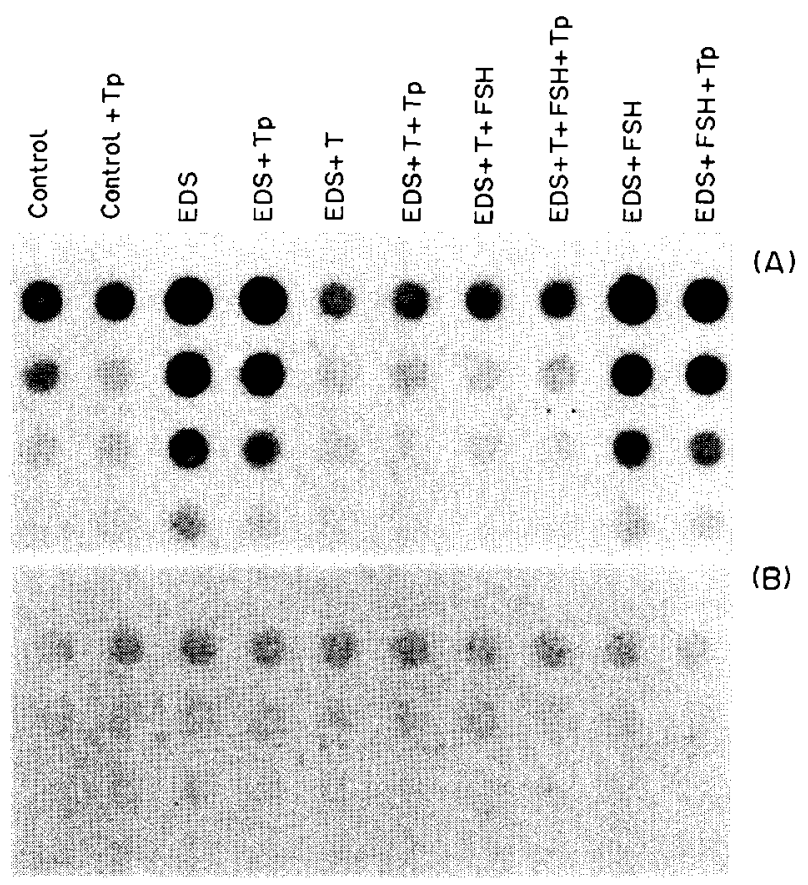

Fig. 2. Dot blot analysis of total RNA extracted from ventral prostate (A) and testis (B). Tp $=$ testosterone injection $(10 \mathrm{mg}) 2 \mathrm{~h}$ prior to killing; EDS = killed 5 days after EDS treatment; $\mathrm{T}=$ substitution with testosterone for 5 days $(15 \mathrm{~cm}$ silastic implants); FSH = substitution with FSH for 5 days $(2 \times 5 \mathrm{IU}$ injected per day). RNA was applied to the filter in two-fold dilution series and analyzed using a human androgen receptor cDNA probe. 
untransformed receptor molecules may have been lost from the nucleus upon cell fractionation, despite the precautions. Therefore, rats in the different experimental groups were treated with a very high dose of testosterone $(10 \mathrm{mg}) 2 \mathrm{~h}$ prior to killing (T-pulse), to retransform androgen receptors to a tight nuclear binding form. The results show that also in the EDS-treated rats that did not carry a $T$ implant (groups 3 and 9), testicular AR were still present and became retransformed to a tight nuclear binding form upon T-pulse treatment (groups 4 and 10 ).

It has been reported that testosterone exerts an effect on the stability of the androgen receptor in various cell culture systems $[6,7]$. The untransformed receptor may undergo a high turnover, which might be markedly reduced upon ligand binding and conversion of the receptor to a tight nuclear binding form. The present results on $\left[{ }^{3} \mathrm{H}\right] \mathrm{R} 1881$ binding, however, seem to indicate that the androgen receptor in the testis is quite stable in the absence of testosterone.

\section{IMMUNOPRECIPITATION OF THE ANDROGEN RECEPTOR}

Immunoprecipitation and Western blotting was performed to confirm the maintenance of the androgen receptor protein in testosterone deprived testis. Using monoclonal and polyclonal antibodies against the $\mathrm{N}$-terminal domain of the human androgen receptor [18], a $116 \mathrm{kDa}$ band was observed (Fig. 3).

In animals treated with EDS and receiving testosterone implants (groups 5-8), the same level of immunoprecipitable androgen receptor was observed as in control animals. However, animals treated with EDS but not receiving testosterone implants (groups 3, 4, 9 and 10), had very low levels of immunoprecipitable androgen receptor. It should be noted that the Western blots represent immunoprecipitation from total testis homogenates, so that loss of androgen receptor from the nuclear fraction does not have an influence on the outcome of the experiments.

The intriguing discrepancy between the results derived from the ligand binding and

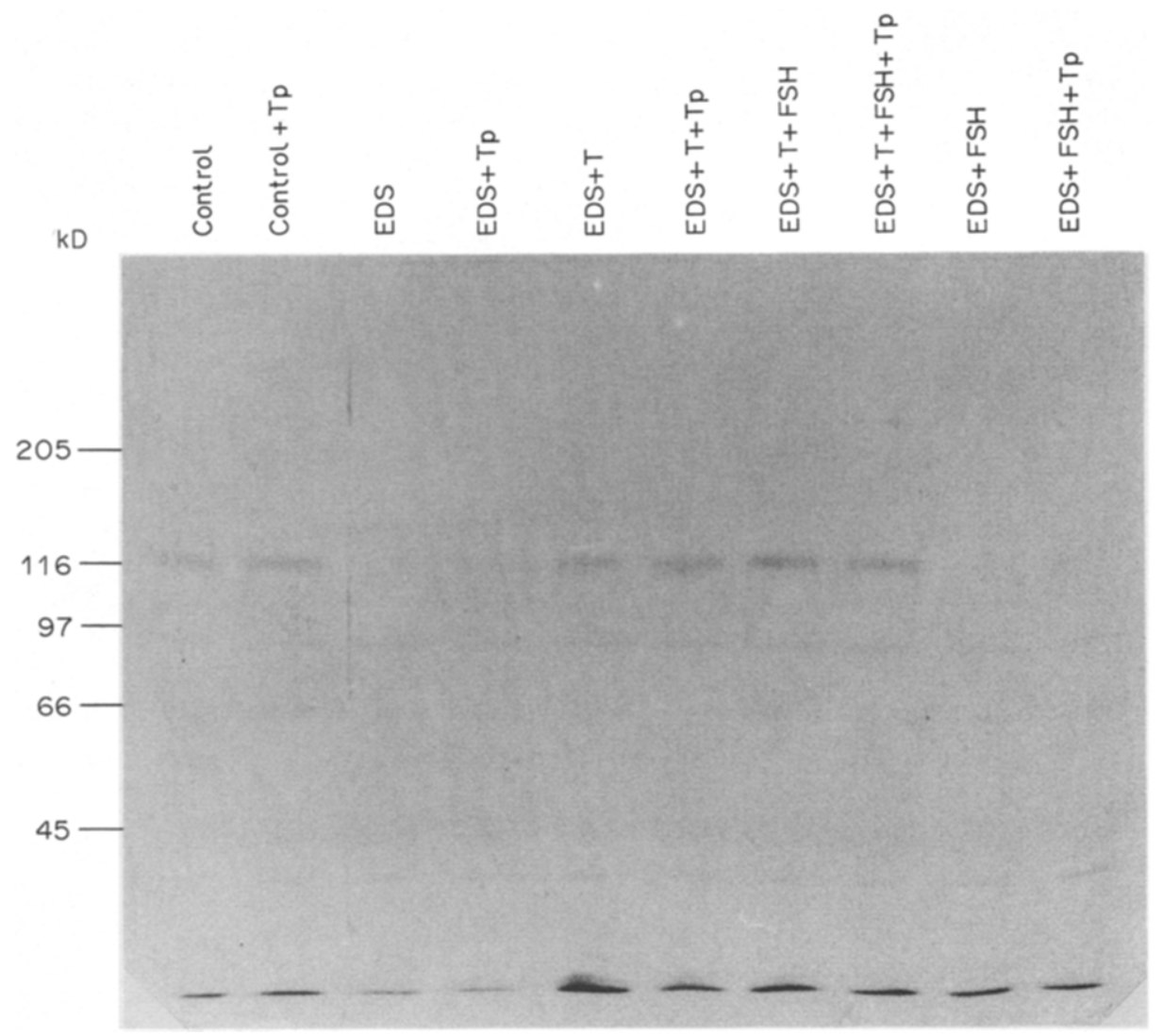

Fig. 3. Western blot analysis of the androgen receptor immunoprecipitated from testis lysates. $\mathrm{T} \mathrm{p}=$ testosterone injection $(10 \mathrm{mg}) 2 \mathrm{~h}$ prior to killing; EDS = killed 5 days after EDS treatment; $\mathrm{T}=$ substitution with testosterone for 5 days $(15 \mathrm{~cm}$ silastic implants); FSH $=$ substitution with FSH for 5 days $(2 \times 5$ IU injected per day). 
immunoprecipitation experiments is not readily explained. Apparently, the antibodies poorly bind to the androgen receptors from testosterone depleted testis (also not after retransformation, $2 \mathrm{~h}$ after injection of a high dose of testosterone). This may point to a permanent structural modification of the untransformed androgen receptor that occurs in the prolonged absence of testosterone. Possibly, the untransformed receptor undergoes proteolytic cleavage, resulting in loss of the $\mathrm{N}$-terminal region which is recognized by the monoclonal antibody used, without a concomitant change in the $\left[{ }^{3} \mathrm{H}\right] \mathrm{R} 1881$ binding. On the other hand, immunoprecipitation of the androgen receptor from the androgen depleted testis may be inhibited through interaction of the androgen receptor with another protein. The exact nature of the putative modification of the androgen receptor will be subject to further investigation.

\section{ROLE OF FSH AND THE TESTICULAR TESTOSTERONE CONCENTRATION}

The present results do not show an effect of FSH treatment on testicular androgen receptor mRNA and protein levels. This can be explained, because the present study concerns total testicular androgen receptors in adult animals, rather than androgen receptors in cultured Sertoli cells from immature rats $[9,10]$.

In the literature, there is an ongoing debate about the testicular testosterone concentration that is needed to maintain spermatogenesis $[16,17]$. An approach based on the present study (EDS-treated rats substituted with different lengths of testosterone implants for 5 days, starting immediately after EDS treatment) may provide a model to try to answer the question at what testosterone concentration the testicular androgen receptor becomes transformed to the tight nuclear binding form. The present results indicate that approximately $20 \%$ of the control testicular androgen concentration may be sufficient to promote complete transformation of the androgen receptor.

\section{REFERENCES}

1. Clermont Y. and Harvey S. C.: Effects of hormones on spermatogenesis in the rat. Ciba Foundation Colloquia on Endocrinology 16 (1967) 173-189.
2. Mainwaring W. I. P.: The mechanism of action of androgens. Monographs on Endocrinology, Springer, Berlin, Vol. 10 (1977) pp. 1-178.

3. Brinkmann A. O., Lindh L. M., Breedveld D. I., Mulder E. and van der Molen H. J.: Cyproterone acetate prevents translocation of the androgen receptor in the rat prostate. Molec. Cell. Endocr. 32 (1983) 117-129.

4. Fiorelli G., Zoppi S., Kohen F. and Motta M.: Synergistic effect of testosterone and a luteinizing hormonereleasing hormone agonist on androgen receptor content in the ventral prostate of castrated rats. Steroids 53 (1989) 195-217.

5. Quarmby V. E., Wendell G. Y., Lubahn D. B., French F.S. and Wilson E. M.: Autologous down-regulation of androgen receptor mRNA. Molec. Endocr. 4 (1990) 22-28.

6. Syms A. J., Norris J. S., Panko W. B. and Smith R. G. Mechanism of androgen receptor augmentation. J. Biol. Chem. 260 (1985) 455-461.

7. Grino P. B., Griffin J. E. and Wilson J. D.: Testosterone at high concentrations interacts with the human androgen receptor similarly to dihydrotestosterone. Endocrinology 126 (1990) 1165-1172.

8. Buzek S. W. and Sanborn B. M.: Increase in testicular androgen receptor during sexual maturation in the rat. Biol. Reprod. 39 (1988) 39-49.

9. Verhoeven $\mathbf{G}$. and Cailleau $\mathbf{J}$.: Follicle stimulating hormone and androgens increase the concentration of the androgen receptor in Sertoli cells. Endocrinology 122 (1988) 1541-1550.

10. Blok L. J., Mackenbach P., Trapman J., Themmen A. P. N., Brinkmann A. O. and Grootegoed J. A.: Follicle stimulating hormone regulates androgen receptor mRNA in Sertoli cells. Molec. Cell. Endocr. 63 (1989) 267-271.

11. Bartlett J. M. S., Kerr J. B. and Sharp R. M.: The effect of selective destruction and regeneration of rat Leydig cells on the intratesticular distribution of testosterone and morphology of the seminiferous tubules. J. Androl. 7 (1986) 240-253.

12. Faber P. W., van Rooij H. C. J., van der Korput H. A. G. M., Baarends W. M., Brinkmann A. O., Grootegoed J. A. and Trapman J.: Characterization of the human androgen receptor transcription unit. J. Biol. Chem. 17 (1991) 10743-10749.

13. Tan J., Joseph D. R., Quarmby V. E., Lubahn D. B., Sar $M$. and French F. S.: The rat androgen receptor: primary structure, autoregulation of its mRNA and immunocytochemical localization of the receptor protein. Molec. Endocr. 2 (1988) 1265-1275.

14. Gorski K., Carneiro M. and Schibler U.: Tissue-specific in vitro transcription from mouse albumin promotor. Cell 47 (1986) 767-776.

15. Husmann D. A., Wilson C. M., McPhaul M. J., Tilley W. D. and Wilson J. D.: Antipeptide antibodies to two distinct regions of the androgen receptor localize the receptor protein to the nuclei of target cells in the rat and human prostate. Endocrinology 126 (1990) 2359-2368.

16. Rommerts F. F. G.: How much androgen is required for maintenance of spermatogenesis? J. Endocr. 116 (1988) 7-9.

17. Sharpe R. M.: Testosterone and spermatogenesis. J. Endocr. 113 (1987) 1-2.

18. van Laar J. H ., Bolt-de Vries J., Zegers N. D. Trapman J. and Brinkmann A. O.: Androgen receptor heterogeneity and phosphorylation in human LNCaP cells. Biochem. Biophys. Res. Commun. 166 (1990) 193-200. 